\title{
Regional monitoring of the urinary tract infections causative agents antibiotic resistance in the child population of the Chernivtsi region
}

\author{
V. V. Bezruk, T. O. Bezruk, L. V. Stegnitska, S. O. Sokolnyk, M. I. Sheremet, \\ V. V. Maksymyuk, O. I. Godovanets, 0. S. Godovanets, A. I. Kovtun \\ Higher State Educational Establishment of Ukraine "Bukovinian State Medical University”, Chernivtsi, Ukraine
}

Key words:

urinary tract

infections,

antibiotic

resistance, children.

Zaporozhye

medical journal

2017; 19 (6), 780-785

DOI:

10.14739/2310-1210

2017.6.115088

E-mail:

vvladimyrbezruk@

gmail.com

In the scope of current medical practice the "viewpoint" regarding the growth of antibiotic resistance of microorganisms is a threat to national security. A reasonable use of antibiotics on the basis of uropathogen regional bacterial sensitivity gives the opportunity to "restrain" the growth of antibiotic resistance of microorganisms and increase the effectiveness of the UTI treatment.

The aim of the article is to determine the range and dynamics of the antibiotic resistance of major groups of infectious-inflammatory diseases causative agents of the urinary tract in the child population of the Chernivtsi region.

Materials and methods. The analysis of etiologic spectrum and antibiotic resistance of uropathogens was conducted and observed in the urine samples of 657 patients who were provided with a specialized medical care in the Nephrology department of the "Municipal Children's Clinical Hospital", Chernivtsi (2014-2015) with the purpose of the dynamic control of possible changes in the regional antibiotic resistance of pathogens of causative pathogens of the "urinary tract infections" (UTI); identify the age and gender differences of the child population of the Chernivtsi region (2014-2015) compared to the monitoring data for the period of 2009-2013.

Results. When UTI among of the child population of the Chernivtsi region leading etiologic organisms include strains of the family Enterobacteriaceae and uropathogen of the genus Proteus. A "wave-like" curve of the dynamics of antibiotic resistance of Enterobacteriaceae uropathogens with a decreasing tendency to the "drugs of choice" was observed among the child population of the region (2009-2015): penicillin $(P<0.01)$, cephalosporin II-III generation $(P<0.01)$ and medicine of the fluoroquinolone series $(P<0.01)$. A "wave-like" curve of the dynamics of antibiotic resistance of Proteus uropathogens with a decreasing tendency to the "drugs of choice" was observed among the child population of the region (2009-2015): semi-synthetic penicillin $(P<0.1)$, and medicine of the tetracycline series $(P<0.01)$.

Conclusions. Regional microbiological monitoring of the uropathogens is an effective "tool" in higher quality treatment of infectious and inflammatory diseases of the urinary tract of the child population.

Ключові слова:

інфекції сечової системи антибіотикорезистентність, Аіти.

\section{Запорізький} медичний журнал. - 2017. -

T. 19, № 6(105). C. $780-785$

\section{Регіональний моніторинг антибіотикорезистентності} збудників інфекцій сечової системи серед Аитячого населення Чернівецької області

В. В. Безрук, Т. О. Безрук, А. В. Стегніцька, С. О. Сокольник, М. І. Шеремет, В. В. Максим'юк, О. І. Годованець, О. С. Годованець, А. І. Ковтун

Сучасний «погляд» у світовій медичній практиці щодо зростання антибіотикорезистентності мікроорганізмів - загроза національної безпеки. Раціональне використання антибіотиків, на підставі даних про регіональну бактеріальну чутливість уропатогенів, дає можливість «стримувати» зростання антибіотикорезистентності мікроорганізмів і підвищити ефективність лікування інфекційно-запальних захворювань сечової системи.

Мета роботи - встановити динаміку антибіотикорезистентності основних груп збудників інфекційно-запальних захворювань сечової системи в дитячого населення Чернівецької області.

Матеріали та методи. Здійснено аналіз етіологічного спектра та антибактеріальної резистентності уропатогенів, що ідентифіковані у 657 зразках сечі пацієнтів, яким надавалась спеціалізована медична допомога у нефрологічному відділенні КМУ «Міська дитяча клінічна лікарня» м. Чернівці (2014-2015рр.), із метою динамічного контролю щодо можливих змін у регіональній антибіотикорезистентності основних груп збудників «інфекцій сечової системи» (ICC); виявлення вікових і гендерних відмінностей у дитячого населення Чернівецької області (2014-2015 рр.) порівняно з отриманими даними моніторингу за період 2009-2013 pp.

Результати. При інфекціях сечовивідних шляхів серед дитячого населення Чернівецької області провідними етіологічними збудниками є штами родини Enterobacteriaceae та уропатогени роду Proteus. Серед дитячого населення регіону із захворюваннями сечовидільної системи спостерігалась (2009-2015рр.) «хвилеподібна» крива динаміки антибіотикорезистентності уропатогенів родини Enterobacteriaceae з тенденцією зниження до «препаратів вибору»: пеніцилінів ( $p<0,01)$, цефалоспоринів II-III поколінь $(p<0,01)$ і препаратів фторхінолонового ряду $(p<0,01)$. Серед уропатогенів роду Proteus спостерігається «Хвилеподібна» крива динаміки антибіотикорезистентності до напівсинтетичних пеніцилінів $(p<0,1)$ і тетрациклінів $(p<0,01)$.

Висновки. Регіональний мікробіологічний моніторинг антибіотикорезистентності основних груп уропатогенів $€$ дієвим «інструментом» у підвищені якості лікування інфекційно-запальних захворювань сечової системи в дітей.

Ключевые слова: инфекция мочевой системы, антибиотикорезистентность, Аети.

\section{Региональный мониторинг антибиотикорезистентности возбудителей инфекций мочевой системы среди детского населения Черновицкой области}

В. В. Безрук, Т. А. Безрук, А. В. Стегницкая, С. А. Сокольник, М. И. Шеремет, В. В. Максимюк, О. И. Годованец, А. С. Годованец, А. И. Ковтун

Современный «взгляд» в мировой медицинской практике относительно роста антибиотикорезистентности микроорганизмов - угроза национальной безопасности. Рациональное использование антибиотиков, на основании данных о региональной 
бактериальной чувствительности уропатогенов, позволяет сдерживать рост антибиотикорезистентности микроорганизмов и повышает эффективность лечения инфекционно-воспалительных заболеваний мочевой системы.

Цель работы - установить динамику антибиотикорезистентности основных групп возбудителей инсрекционно-воспалительных заболеваний мочевой системы у детского населения Черновицкой области.

Материалы и методы. Проведен анализ этиологического спектра и антибактериальной резистентности уропатогенов (идентифицированных в 657 образцах мочи пациентов, которым оказывалась специализированная медицинская помощь в нефрологическом отделении КГУ «Городская детская клиническая больница» г. Черновцы (2014-2015 гг.)) с целью динамического контроля региональной антибиотикорезистентности среди основных групп возбудителей «инфеекцй мочевой системы» (ИМС); выявление возрастных и гендерных различий среди детского населения Черновицкой области (20142015 гг.) в сравнении с полученными ранее данными мониторинга за период 2009-2013 гг.

Результаты. При инфекциях мочевыводящих путей среди детского населения Черновицкой области ведущими этиологическими возбудителями являются штаммы семейства Enterobacteriaceae и уропатогены рода Proteus. Среди детского населения региона с заболеваниями мочевыделительной системы наблюдалась (2009-2015 гг.) «волнообразная» кривая динамики антибиотикорезистентности уропатогенов семейства Enterobacteriaceae с тенденцией снижения к «препаратам выбора»: пенициллинам ( $<<0,01)$, цефралоспоринам II-III поколения ( $<0,01)$ и препаратам фрторхинолонового ряда $(p<0,01)$. Среди уропатогенов рода Proteus наблюдается «волнообразная» кривая динамики антибиотикорезистентности к полусинтетическим пенициллинам ( $p<0,1)$ и препаратам тетрациклинового ряда $(p<0,01)$.

Выводы. Региональный микробиологический мониторинг антибиотикорезистентности основных групп уропатогенов является действенным «инструментом» в повышении качества лечения инфекционно-воспалительных заболеваний мочевой системы у детей.

The urinary tract infections (UTI) are stated to be the global issue in the health service of the world and, particularly, in Ukraine; findings considering the uropathogenic resistance of antibiotic medications differ, therefore regional peculiarities of their antibiotic resistance are to be investigated [4-6].

\section{Purpose}

The aim of the article is to determine the range and dynamics of the antibiotic resistance of majority groups of infectious-inflammatory diseases causative agents of the urinary tract in the child population of the Chernivtsi region.

\section{Materials and methods}

The analysis of etiologic spectrum and antibiotic resistance of uropathogens was conducted and observed in the urine samples of 657 patients provided with a specialized medical care in the Nephrology department at the "Municipal Children's Clinical Hospital", Chernivtsi (2014-2015) (Table 1).

The main group has comprised patients having been diagnosed with infectious-inflammatory diseases of the urinary tract according to the MKX-10 № 10-11.1 Renal infections. The comparison group has included the patients with non infectious-inflammatory diseases of the urinary tract with nosological code according to MKX-10: N00 acute nephrotic syndrome; № 03 chronic nephrotic syndrome; № 04 nephrotic syndrome; № 15 Other renal tubulointerstitial diseases; № 18 Chronic kidney insufficiency; № 39 Other disorders of the urinary system; № 39.2 Orthostatic proteinuria, unspecified; R30 Pain in urination; R30.1 Vesical tenesmus; R32 Urinary incontinence, unspecified.

It should be mentioned that for statistical handling and subsequent analysis of the gained data, only the results of the initial examination in both groups have been selected: the main group - 330 children (68.46\% of the examined patients) and the comparison groups 115 children $(65.71 \%$ of the examined patients).

The bacteriological research of the urine samples have been provided on the basis of microbiological research sector of the medico-ecological problems (Chernivtsi) of "L. I. Medved's Research Center of Preventive Toxicology, Food and Chemical Safety, Ministry of Health, Ukraine (State Enterprise)", Kyiv; family and genus identification of the isolated strains have been conducted applying conventional methods of microbiology. The strains with their exceeded amount in $1 \mathrm{ml}$ of urine or with their amount near to $1 \times 103$ of colony forming units (CFU) in a case of enterobacteria-isolation were considered to be significant ones. During the pseudomonads isolation, Staphylococcus aureus, the yeast-like fungi were associated with etiologically significant ones, whereas their amount to be at least $1 \times 102 \mathrm{CFU}$ in $1 \mathrm{ml}$ of urine. The detection of bacterial strains antibiotic sensibility was conducted according to the order of the Ministry of Health of Ukraine № 167 from 05. 04. 2007. "On the approval of guidelines to determine the sensitivity of microorganisms to antibiotics".

The objective aims at the dynamic control of possible changes in the regional antibiotic resistance of causative pathogens of the "urinary tract infections" (UTI); as well as to identify the age and gender differences of the child population in the Chernivtsi region (2014-2015) compared to the monitoring data for the period of 2009-2013 years [1-3].

Statistical handling of the results - evaluation of the percentage data computed with Fisher angle transformation. Percentage differences in the group were evaluated with Chi-square $\left(c^{2}\right)$ Pearson criteria [7].

Table 1. Age and gender distribution of the examined children in Chernivtsi region with urinary tract diseases

\begin{tabular}{lllll}
\hline $\begin{array}{l}\text { Age of the } \\
\text { examined patients }\end{array}$ & \multicolumn{2}{l}{$\begin{array}{l}\text { The main group of patients } \\
(\mathbf{n}=\mathbf{4 8 2})\end{array}$} & $\begin{array}{l}\text { The comparison group } \\
(\mathbf{n}=175)\end{array}$ \\
\cline { 2 - 5 } & \begin{tabular}{llll} 
Gender of the examined patients \\
\cline { 2 - 5 }
\end{tabular} & male & fender of the examined patients \\
\hline under 3 years & 50 & 162 & male & female \\
4-6 years & 18 & 72 & 5 & 24 \\
7-14 years & 29 & 90 & 8 & 25 \\
15-18 years & 20 & 41 & 28 & 36 \\
\hline
\end{tabular}

Запорожский медицинский журнал. - 2017. T. 19, № 6(105). C. $780-785$ 

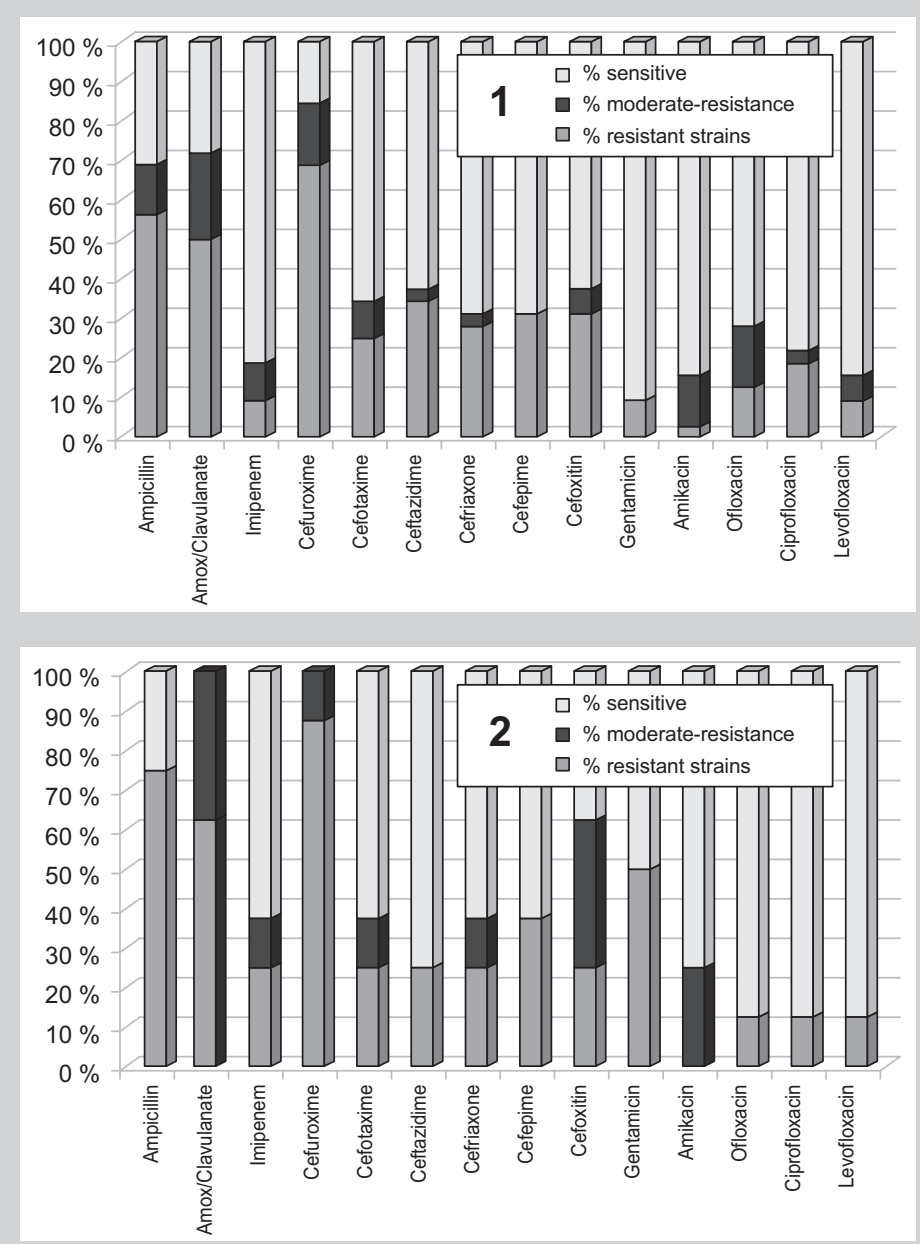

Fig. 1. Antibiotic resistance of the causative pathogens strains of the family Enterobacteriaceae (excluded Proteus) was isolated in the examined patients during the 2014-2015 years.

1: infectious-inflammatory diseases of the urinary tract;

2: non-infectious diseases of the urinary tract.

\section{Results and discussion}

The etiologic spectrum of causative pathogens strains collected from patients' urine enclosed strains of the family Enterobacteriaceae, non-fermenting Gram-negative bacteria (family Pseudomonas and Alcaligenes); staphylococci (S. aureus, S. epidermidis), enterococci (E. faecalis), streptococci (S. Pyogenes), the yeast-like fungi (C. albicans).

The monitoring results for the period of 2009-2013 years [1-3] and obtained data of 2014-2015 observation years state that strains of the family Enterobacteriaceae (excluded Proteus) prevail in microbial "landscape" in the child urine of the region; at the same time, it is worth to draw the attention to differences considering antibiotic sensitivity in UTI and non-infectious diseases of the urinary tract (Fig. 1).

Enterobacteriaceae strains (excluded Proteus) isolated from the urine of the patients with non-infectious pathology of the urinary tract (comparison group), basically, were more resistant to all used in the research, $\beta$-lactam antibiotics and aminoglycoside in comparison with the strains isolated from the urine of children with UTI (the main group). At the same time a decreasing sensitivity to the strains of the family Enterobacteriaceae (excluded Proteus) to the medications of the fluoroquinolone class is preserved among the children with UTI (2014-2015 years), which has been fixed in 2009-2013 years of observation [2,3] in comparison with enterobacteria strains isolated from the urine of the patients with non-infectious diseases of urinary tract.

The monitoring results ( of 2009-2015 years) state, that among the child population of Chernivtsi region in UTI a "wave-like" curve of the dynamics of antibiotic resistance of uropathogens of the family Enterobacteriaceae with a decreasing tendency to the "drugs of choice" was observed: penicillins $(P<0.01)$, cephalosporins II-III generation $(P<0.01)$ and medications of the fluoroquinolone class $(P<0.01)$; and antibiotic resistance of Proteus uropathogens - to semi-synthetic penicillins $(P<0.1)$, and medications of the tetracycline class $(P<0.01)($ Tables $2-3)$.

Table 2. Dynamics of the antibiotic resistance of the family Enerobacteriaceae uropathogens (excluded Proteus) as an etiological cause of the infectious-inflammatory diseases of the urinary tract in children of Chernivtsi region

\begin{tabular}{|c|c|c|c|c|c|c|c|c|}
\hline Antibiotics & Year & 2009 & 2010 & 2011 & 2012 & 2013 & 2015 & 2016 \\
\hline \multirow[t]{4}{*}{ Ampicillin } & $\%$ resistant strains & - & - & - & $64 \pm 6.79$ & $55.2 \pm 4.62$ & $64.2 \pm 5.86$ & $70.8 \pm 9.28$ \\
\hline & $\mathrm{n}$ & - & - & - & 50 & 116 & 67 & 24 \\
\hline & $\chi^{2}$ & - & - & - & - & 1.110 & 1.417 & 0.343 \\
\hline & $\mathrm{P}$ & - & - & - & - & $P>0.1$ & $P>0.1$ & $p>0.1$ \\
\hline \multirow[t]{3}{*}{ Carbenicillin } & $\%$ resistant strains & $57.4 \pm 4.61$ & $52.8 \pm 4.80$ & $59.1 \pm 4.80$ & $59.1 \pm 7.41$ & - & - & - \\
\hline & $\mathrm{n}$ & 115 & 108 & 105 & 44 & - & - & - \\
\hline & $\mathrm{P}$ & - & $P>0.1$ & $P>0.1$ & $P>0.1$ & - & - & - \\
\hline \multirow{4}{*}{$\begin{array}{l}\text { Amoxicillin/ } \\
\text { Clavulanate }\end{array}$} & $\%$ resistant strains & - & - & - & $70 \pm 6.48$ & $46.6 \pm 4.63$ & $56.7 \pm 6.05$ & $66.7 \pm 9.62$ \\
\hline & $\mathrm{n}$ & - & - & - & 50 & 116 & 67 & 24 \\
\hline & $\chi^{2}$ & - & - & - & - & 7.694 & 1.733 & 0.732 \\
\hline & $\mathrm{P}$ & - & - & - & - & $P<0.01$ & $P>0.1$ & $p>.1$ \\
\hline \multirow[t]{3}{*}{ Imipenem } & $\%$ resistant strains & - & - & - & 0 & $0.9 \pm 0.88$ & $11.9 \pm 3.96$ & $33.3 \pm 9.62$ \\
\hline & $\mathrm{n}$ & - & - & - & 50 & 116 & 67 & 24 \\
\hline & $\mathrm{P}$ & - & - & - & - & $P>0.1$ & $P<0.01$ & $P<0.01$ \\
\hline \multirow[t]{4}{*}{ Cefalexin } & $\%$ resistant strains & $17.4 \pm 11.43$ & $21.2 \pm 4.43$ & $22.9 \pm 4.10$ & $20.1 \pm 6.04$ & - & - & - \\
\hline & $\mathrm{n}$ & 11 & 85 & 105 & 44 & - & - & - \\
\hline & $\chi^{2}$ & - & 0.085 & 0.079 & 0.141 & - & - & - \\
\hline & $P$ & - & $P>0.1$ & $P>0.1$ & $P>0.1$ & - & - & - \\
\hline
\end{tabular}


Cont. Table 2

\begin{tabular}{|c|c|c|c|c|c|c|c|c|}
\hline Antibiotics & Year & 2009 & 2010 & 2011 & 2012 & 2013 & 2015 & 2016 \\
\hline \multirow[t]{4}{*}{ Cefuroxime } & $\%$ resistant strains & - & - & - & $28.2 \pm 7.21$ & $16.4 \pm 3.44$ & $67.2 \pm 5.74$ & $41.7 \pm 10.06$ \\
\hline & $\mathrm{n}$ & - & - & - & 39 & 116 & 67 & 24 \\
\hline & $\chi^{2}$ & - & - & - & - & 2.602 & 48.176 & 4.807 \\
\hline & $P$ & - & - & - & - & $P>0.1$ & $P<0.01$ & $P<0.01$ \\
\hline \multirow[t]{3}{*}{ Cefotaxime } & $\%$ resistant strains & - & - & - & $16 \pm 5.18$ & $12.1 \pm 3.03$ & $25.4 \pm 5.32$ & $33.3 \pm 9.62$ \\
\hline & $\mathrm{n}$ & - & - & - & 50 & 116 & 67 & 24 \\
\hline & $P$ & - & - & - & - & $P>0.1$ & $P<0.01$ & $P>0.1$ \\
\hline \multirow[t]{4}{*}{ Ceftazidime } & $\%$ resistant strains & $7.8 \pm 2.50$ & $17.6 \pm 3.66$ & $4.8 \pm 2.09$ & $11.7 \pm 3.32$ & $9.8 \pm 2.76$ & $32.8 \pm 5.74$ & $37.5 \pm 9.88$ \\
\hline & $\mathrm{n}$ & 115 & 108 & 105 & 94 & 116 & 67 & 24 \\
\hline & $\chi^{2}$ & & 4.875042 & 8.709278 & 3.186818 & 0.196976 & 15.07744 & 0.173849 \\
\hline & $\mathrm{P}$ & & $P<0.01$ & $P<0.01$ & $P<0.1$ & $P>0.1$ & $P<0.01$ & $P>0.1$ \\
\hline \multirow[t]{3}{*}{ Cefoperazone } & $\%$ resistant strains & $13.7 \pm 3.40$ & $13.9 \pm 3.44$ & $15.2 \pm 3.50$ & $17.1 \pm 5.88$ & - & - & - \\
\hline & $\mathrm{n}$ & 102 & 101 & 105 & 41 & - & - & - \\
\hline & $\mathrm{P}$ & - & $P>0.1$ & $P>0.1$ & $P>0.1$ & - & - & - \\
\hline \multirow[t]{4}{*}{ Ceftriaxone } & $\%$ resistant strains & $10.4 \pm 2.85$ & $14.0 \pm 29.2$ & $9.5 \pm 2.86$ & $12.8 \pm 3.45$ & $12.9 \pm 3.11$ & $26.9 \pm 5.42$ & $33.3 \pm 9.62$ \\
\hline & $\mathrm{n}$ & 115 & 107 & 105 & 94 & 116 & 67 & 24 \\
\hline & $\chi^{2}$ & - & 0.674 & 1.033 & 0.549 & 0.000 & 5.633 & 0.355 \\
\hline & $P$ & - & $P>0.1$ & $P>0.1$ & $P>0.1$ & $P>0.1$ & $P<0.01$ & $P>0.1$ \\
\hline \multirow[t]{4}{*}{ Cefazolin } & $\%$ resistant strains & $23.6 \pm 4.12$ & $29.2 \pm 4.64$ & $19.1 \pm 3.84$ & $5.9 \pm 4.04$ & - & - & - \\
\hline & $\mathrm{n}$ & 106 & 96 & 105 & 34 & - & - & - \\
\hline & $\chi^{2}$ & - & 0.816 & 2.811 & 3.352 & - & - & - \\
\hline & $\mathrm{P}$ & - & $P>0.1$ & $P<0.1$ & $P<0.1$ & - & - & - \\
\hline \multirow[t]{4}{*}{ Cefepime } & $\%$ resistant strains & - & - & - & $14 \pm 4.91$ & $12.1 \pm 3.03$ & $34.3 \pm 5.80$ & $33.3 \pm 9.62$ \\
\hline & $\mathrm{n}$ & - & - & - & 50 & 116 & 67 & 24 \\
\hline & $\chi^{2}$ & - & - & - & - & 0.114 & 12.971 & 0.008 \\
\hline & $\mathrm{P}$ & - & - & - & - & $P>0.1$ & $P<0.01$ & $P>0.1$ \\
\hline \multirow[t]{3}{*}{ Cefoxitin } & $\%$ resistant strains & - & - & - & $20 \pm 5.66$ & $13.8 \pm 3.20$ & $37.3 \pm 5.91$ & $91.7 \pm 5.63$ \\
\hline & $\chi^{2}$ & - & - & - & - & 1.017 & 13.491 & 20.940 \\
\hline & $\mathrm{P}$ & - & - & - & - & $P>0.1$ & $P<0.01$ & $P<0.01$ \\
\hline \multirow[t]{4}{*}{ Ofloxacin } & $\%$ resistant strains & $8.3 \pm 2.82$ & $11.1 \pm 3.16$ & $11.4 \pm 3.10$ & $20.4 \pm 4.18$ & $8.6 \pm 2.60$ & $9.0 \pm 3.50$ & $16.7 \pm 7.61$ \\
\hline & $\mathrm{n}$ & 96 & 99 & 105 & 93 & 116 & 67 & 24 \\
\hline & $\chi^{2}$ & - & 0.435 & 0.005 & 3.030 & 6.023 & 0.009 & 1.068 \\
\hline & $\mathrm{P}$ & - & $P>0.1$ & $P>0.1$ & $P<0.1$ & $P<0.01$ & $P>0.1$ & $P>0.1$ \\
\hline \multirow[t]{4}{*}{ Ciprofloxacin } & $\%$ resistant strains & $11.3 \pm 2.95$ & $7.4 \pm 2.52$ & $13.7 \pm 3.40$ & $20.2 \pm 4.14$ & $8.6 \pm 2.60$ & $11.9 \pm 3.96$ & $16.7 \pm 7.61$ \\
\hline & $\mathrm{n}$ & 115 & 108 & 102 & 94 & 116 & 67 & 24 \\
\hline & $\chi^{2}$ & - & 0.994 & 2.223 & 1.477 & 5.876 & 0.523 & 0.356 \\
\hline & $\mathrm{P}$ & - & $P>0.1$ & $P>0.1$ & $P>0.1$ & $P<0.01$ & $P>0.1$ & $P>0.1$ \\
\hline \multirow[t]{4}{*}{ Pefloxacin } & $\%$ resistant strains & $17.4 \pm 3.54$ & $18.5 \pm 3.74$ & $17.1 \pm 3.67$ & $15.4 \pm 7.08$ & - & - & - \\
\hline & $\mathrm{n}$ & 115 & 108 & 105 & 26 & - & - & - \\
\hline & $\chi^{2}$ & - & 0.046 & 0.071 & 0.043 & - & - & - \\
\hline & $\mathrm{P}$ & - & $P>0.1$ & $P>0.1$ & $P>0.1$ & - & - & - \\
\hline \multirow[t]{4}{*}{ Levofloxacin } & $\%$ resistant strains & - & - & - & $10.0 \pm 4.24$ & $4.3 \pm 1.88$ & $6.0 \pm 2.90$ & $20.8 \pm 8.28$ \\
\hline & $\mathrm{n}$ & - & - & - & 50 & 116 & 67 & 24 \\
\hline & $\chi^{2}$ & - & - & - & - & 2.007 & 0.262 & 4.338 \\
\hline & $\mathrm{P}$ & - & - & - & - & $P>0.1$ & $P>0.1$ & $P<0.01$ \\
\hline \multirow[t]{4}{*}{ Tetracycline } & $\%$ resistant strains & $36.5 \pm 4.49$ & $43.5 \pm 4.77$ & $39.4 \pm 4.79$ & $63.6 \pm 7.25$ & - & - & - \\
\hline & $\mathrm{n}$ & 115 & 108 & 104 & 44 & - & - & - \\
\hline & $\chi^{2}$ & - & 1.138 & 0.367 & 7.277 & - & - & - \\
\hline & $\mathrm{P}$ & - & $P>0.1$ & $P>0.1$ & $P<0.01$ & - & - & - \\
\hline \multirow[t]{4}{*}{ doxycycline } & $\%$ resistant strains & $33.9 \pm 4.41$ & $49.1 \pm 4.81$ & $43.8 \pm 4.84$ & $56.8 \pm 7.47$ & - & - & - \\
\hline & $\mathrm{n}$ & 115 & 108 & 105 & 44 & - & - & - \\
\hline & $\chi^{2}$ & - & 5.309 & 0.601 & 2.101 & - & - & - \\
\hline & $\mathrm{P}$ & - & $P<0.01$ & $P>0.1$ & $P>0.1$ & - & - & - \\
\hline Gentamicin & $\%$ resistant strains & $11.3 \pm 2.95$ & $5.6 \pm 2.22$ & $11.3 \pm 3.21$ & $3.2 \pm 1.82$ & 0 & $14.9 \pm 4.35$ & $16.7 \pm 7.61$ \\
\hline & $\mathrm{n}$ & 115 & 107 & 97 & 94 & 116 & 67 & 24 \\
\hline
\end{tabular}


Cont. Table 2

\begin{tabular}{|c|c|c|c|c|c|c|c|c|}
\hline Antibiotics & Year & 2009 & 2010 & 2011 & 2012 & 2013 & 2015 & 2016 \\
\hline \multirow[t]{4}{*}{ Amikacin } & $\%$ resistant strains & - & - & - & $8.0 \pm 3.84$ & $0.9 \pm 0.88$ & $6.0 \pm 2.90$ & $8.3 \pm 5.63$ \\
\hline & $n$ & - & - & - & 50 & 116 & 67 & 24 \\
\hline & $\chi^{2}$ & - & - & - & - & 5.978 & 4.106 & 0.151 \\
\hline & $P$ & - & - & - & - & $P<0.01$ & $P<0.01$ & $P>0.1$ \\
\hline \multirow[t]{3}{*}{ Kanamycin } & $\%$ resistant strains & $14.9 \pm 3.34$ & $30.6 \pm 4.43$ & $18.1 \pm 3.76$ & $19.1 \pm 8.58$ & - & - & - \\
\hline & $n$ & 114 & 108 & 105 & 21 & - & - & - \\
\hline & $\mathrm{P}$ & - & $P<0.01$ & $P<0.01$ & $P>0.1$ & - & - & - \\
\hline \multirow[t]{4}{*}{ Levomycetin } & $\%$ resistant strains & $26.1 \pm 4.10$ & $20.4 \pm 3.88$ & $20.0 \pm 3.90$ & $22.7 \pm 6.32$ & - & - & - \\
\hline & $\mathrm{n}$ & 115 & 108 & 105 & 44 & - & - & - \\
\hline & $\chi^{2}$ & - & 1.011 & 0.005 & 0.137 & - & - & - \\
\hline & $\mathrm{P}$ & - & $P>0.1$ & $P>0.1$ & $P>0.1$ & - & - & - \\
\hline
\end{tabular}

Research is not carried out.

Table 3. Dynamics of the antibiotic resistance of the genus Proteus, as an etiological cause of the infectious-inflammatory diseases of the urinary tract in children of Chernivtsi region

\begin{tabular}{|c|c|c|c|c|c|c|c|}
\hline Antibiotics & Year & 2009 & 2010 & 2011 & 2012 & 2013 & 2015 \\
\hline \multirow[t]{4}{*}{ Ampicillin } & $\%$ resistant strains & - & - & - & $15.4 \pm 10.01$ & $45.8 \pm 10.17$ & $36.8 \pm 11.06$ \\
\hline & $\mathrm{n}$ & - & - & - & 13 & 24 & 19 \\
\hline & $\chi^{2}$ & - & - & - & - & 3.420116 & 0.353032 \\
\hline & $P$ & - & - & - & - & $P<0.1$ & $P>0.1$ \\
\hline \multirow[t]{3}{*}{ Carbenicillin } & $\%$ resistant strains & $32 \pm 9.33$ & $4.3 \pm 4.23$ & $13.2 \pm 8.74$ & 0 & - & - \\
\hline & $\mathrm{n}$ & 25 & 23 & 15 & 10 & - & - \\
\hline & $P$ & - & $P<0.01$ & $P>0.1$ & $P>0.1$ & - & - \\
\hline \multirow[t]{4}{*}{ Imipenem } & $\%$ resistant strains & - & - & - & $7.7 \pm 7.39$ & 0 & $21.1 \pm 9.36$ \\
\hline & $\mathrm{n}$ & - & - & - & 13 & 24 & 19 \\
\hline & $\chi^{2}$ & - & - & - & - & 1.899386 & 5.584673 \\
\hline & $\mathrm{P}$ & - & - & - & - & $P>0.1$ & $P<0.01$ \\
\hline \multirow[t]{3}{*}{ Tetracycline } & $\%$ resistant strains & $96 \pm 3.92$ & $56.5 \pm 10.34$ & $40 \pm 12.65$ & $70 \pm 14.49$ & - & - \\
\hline & $\mathrm{n}$ & 25 & 23 & 15 & 10 & - & - \\
\hline & $\mathrm{P}$ & - & $\mathrm{P}<0.01$ & $P>0.1$ & $P>0.1$ & - & - \\
\hline \multirow[t]{4}{*}{ Doxicycline } & $\%$ resistant strains & $96 \pm 3.92$ & $65.2 \pm 9.93$ & $66.7 \pm 12.17$ & $80 \pm 12.65$ & - & - \\
\hline & $\mathrm{n}$ & 25 & 23 & 15 & 10 & - & - \\
\hline & $\chi^{2}$ & - & 7.456842 & 0.009076 & 0.526688 & - & - \\
\hline & $\mathrm{P}$ & - & $P<0.01$ & $P>0.1$ & $P>0.1$ & - & - \\
\hline \multirow[t]{4}{*}{ Levomycetin } & $\%$ resistant strains & $52 \pm 9.99$ & $17.4 \pm 7.90$ & $26.7 \pm 11.42$ & $30 \pm 14.49$ & - & - \\
\hline & $\mathrm{n}$ & 25 & 23 & 15 & 10 & - & - \\
\hline & $\chi^{2}$ & - & 6.269423 & 0.472149 & 0.032397 & - & - \\
\hline & $\mathrm{P}$ & - & $P<0.01$ & $P>0.1$ & $P>0.1$ & - & - \\
\hline
\end{tabular}

Research is not carried out.

\section{Conclusions}

1. In UTI among of the child population of the Chernivtsi region leading etiologic causative agents are observed to be strains of the family Enterobacteriaceae and uropathogenic of the genus Proteus.

2. A "wave-like" curve of the dynamics of antibiotic resistance of Enterobacteriaceae uropathogens with a decreasing tendency to the "drugs of choice" was observed among the child population of the region (of 2009-2015 years): penicillins $(P<0.01)$, cephalosporins II-III generation $(P<0.01)$ and medications of the fluoroquinolone class $(P<0.01)$. A "wave-like" curve of the dynamics of antibiotic resistance of Proteus uropathogens with a decreasing tendency to the "drugs of choice" was observed among the child population of the region (of 2009-2015 years): semi-synthetic penicillins $(P<0.1)$, and medications of the tetracycline class $(P<0.01)$.

3. Regional microbiological monitoring of the uropathogens is an effective "tool" in treatment efficiency enhancement of infectious and inflammatory diseases of the urinary tract among the child population.

Prospects of the future research directed towards dynamic control of the regional monitoring among the child population in Chernivtsi region.

\section{References}

[1] Bezruk, V., Blinder, O., Bezruk, T., Blinder, O., \& Yurniuk, S. (2014) Etiological structure of the urinary system infections. its dynamic, dependence on patients sex and relation with resident urine microflora among inhabitants of Chernivtsi region and town of Chernivtsi, Canadian Scientific Journal, 2, 25-35. 
[2] Bezruk, V. V. (2015). Infektsii sechovoi systemy u ditei: etiolohichna struktura, vikovi ta henderni osoblyvosti [Urinary Tract Infection in Children: Etiological Structure. Age and Gender Characteristics]. Zdorov'e rebenka. 7(67). 113-117. [in Ukrainian].

[3] Bezruk, V. V., Blinder, O. V., Bezruk, T. O., Blinder, O. O., \& Deyneka, S. E. (2015). Antybiotykorezystentnist osnovnykh hrup zbudnykiv infektsiy sechovoyi systemy [Antimicrobial resistance in pathogens causing urinary tract infections]. Ukrainskyi zhurnal nefrolohii ta dializu 4, 9-15. [in Ukrainian].

[4] Grabe, M., Bjerklund-Johansen, T. E., Botto, H., Çek, M., Naber, K. G. Pickard, R. S., et al. (2013) Guidelines on urological infections

[5] Head, M. G., Fitchett, J. R., Cooke, M. K., Wurie, F. B., Atun, R., Hayward, A. C., et al. (2014) Systematic analysis of funding awarded for antimicrobial resistance research to institutions in the UK, 1997-2010, J Antimicrob Chemother, 69, 548-554. doi: 10.1093/jac/dkt349.

[6] Howard, S. J., Catchpole, M., Watson, J., \& Davies, S. C. (2013) Antibiotic resistance: global response needed. Lancet Infect Dis., 13, 1001-1003. doi: 10.1016/S1473-3099(13)70195-6.

[7] Rosner, B., (2010) Fundamentals of Biostatistics. Duxbury Press. Belmont. CA.

\section{Information about authors:}

Bezruk V. V., PhD. Associate Professor of the Department

of Pediatrics, neonatology and perinatology of medicine, Higher

State Educational Establishment of Ukraine "Bukovinian State

Medical University", Chernivtsi, Ukraine.

Researcher ID: B-8621-2017

Bezruk T. 0., PhD, Associate Professor of the Department of the Internal Medicine, Higher State Educational Establishment of Ukraine "Bukovinian State Medical University", Chernivtsi, Ukraine.

Researcher ID: c-9965-2017

Stegnitska L. V., Teacher of the Department of Foreign Languages, Higher State Educational Institution of Ukraine "Bukovinian State Medical University", Chernivtsi, Ukraine.

Researcher ID: C-5075-2017

Sokolnyk S. O., Doctor of Medical Sciences, PhD, Associate Professor of the Department of Pediatric Surgery and Otolaryngology, Higher State Educational Establishment of Ukraine "Bukovinian State Medical University", Chernivtsi, Ukraine.

Researcher ID: B-9306-2017

Sheremet M. I., PhD, Associated Professor of Surgery Department № 1, Higher State Educational Establishment of Ukraine "Bukovinian State Medical University", Chernivtsi, Ukraine. Researcher ID: B-4388-2017

Maksymyuk V. V., Doctor of Medical Sciences, PhD, Professor of Surgery Department № 1, Higher State Educational Establishment of Ukraine "Bukovinian State Medical University", Chernivtsi, Ukraine.

Researcher ID: B-5128-2017

Godovanets O. I., Doctor of Medical Sciences, PhD, Associate Professor of the Department of Surgical and Pediatric Stomatology, Higher State Educational Establishment of Ukraine "Bukovinian State Medical University", Chernivtsi, Ukraine.

Researcher ID: B-7111-2017

Godovanets 0. S., PhD, Assistant of the Department of Pediatrics, neonatology and perinatology of medicine, Higher State

Educational Establishment of Ukraine "Bukovinian State Medical

University", Chernivtsi, Ukraine.

Researcher ID: B-1224-2017

Kovtun A. I., PhD, Associate Professor of the Department

of Anaesthesiology and Reanimatology, Higher State Educationa

Establishment of Ukraine "Bukovinian State Medical University",

Chernivtsi, Ukraine.

Researcher ID: C-8245-2017

\section{Відомості про авторів:}

Безрук В. В., канд. меА. наук, Аоцент каф. педіатрії, неонатології та перинатальної меАицини, ВАНЗ України “Буковинський Аержавний медичний університет", м. Чернівці, Україна.

Безрук Т. О., канА. меА. наук, Аоцент каф. внутрішньої меАицини та інфекційних хвороб, ВАНЗ України “Буковинський Аержавний медичний університет", м. Чернівці, Україна.

Стегніцька ^. В., викладач каф. іноземних мов, ВАНЗ України "Буковинський державний медичний університет", м. Чернівці, Україна.
Сокольник С. О., А-р меА. наук, Аоцент каф. Аитячої хірургіі та отоларингології, ВАНЗ України “Буковинський Аержавний медичний університет", м. Чернівці, Україна.

Шеремет М. І., канА. меА. наук, Аоцент каф. хірургії № 1,

ВАНЗ України "Буковинський державний меАичний університет", м. Чернівці, Україна.

Максим'юк В. В., А-р меА. наук. професор каф. хірургії № 1 ,

ВАНЗ України “Буковинський державний медичний університет", м. Чернівці, Україна.

Годованець О. І., А-р меА. наук, Аоцент каф. хірургічної та Аитячої стоматології, ВАНЗ України “Буковинський Аержавний медичний університет", м. Чернівці, Україна.

Годованець О. С., канА. меА. наук, асистент каф. педіатрії, неонатології та перинатальної меАицини, ВАНЗ України "Буковинський державний медичний університет", м. Чернівці, Україна.

Ковтун А. І., канА. меА. наук, Аоцент каф. анестезіології та реаніматології, ВАНЗ України “Буковинський державний медичний університет", м. Чернівці, Україна.

\section{Сведения об авторах:}

Безрук В. В., канА. меА. наук, Аоцент каф. педиатрии, неонатологии и перинатальной медицины, ВГУЗ Украины "Буковинский государственный меАицинский университет", г. Черновцы, Украина.

Безрук Т. А., канА. меА. наук, Аоцент каф. внутренней медицинь и инфекционных болезней, ВГУЗ Украины “Буковинский государственный медицинский университет", г. Черновцы, Украина.

Стегницкая ^. В., преподаватель каф. иностранных языков, ВГУЗ Украины «Буковинский государственный медицинский университет", г. Черновцы, Украина.

Сокольник С. А., А-р меА. наук, Аоцент каф. Аетской хирургии и отоларингологии, ВГУЗ Украины «Буковинский государственный медицинский университет», г. Черновцы, Украина.

Шеремет М. И., канА. меА. наук, Аоцент каф. хирургии № 1 , ВГУЗ Украины "Буковинский государственный медицинский университет", г. Черновцы, Украина.

Максимюк В. В., А-р меА. наук, профессор каф. хирургии № 1, ВГУЗ Украины “Буковинский государственный медицинский университет", г. Черновцы, Украина

Годованец О. И., А-р меА. наук, Аоцент каф. хирургической и детской стоматологии, ВГУЗ Украины “Буковинский государственный медицинский университет", г. Черновцы, Украина.

Годованец А. С., канА. меА. наук, ассистент каф. педиатрии, неонатологии и перинатальной медицины, ВГУЗ Украинь "Буковинский государственный меАицинский университет", г. Черновцы, Украина.

Ковтун А. И., канд. меА. наук, Аоцент каф. анестезиологии и реаниматологии, ВГУЗ Украины “Буковинский государственный медицинский университет", г. Черновцы, Украина.

Конфлікт інтересів: віАсутній

Conflicts of Interest: authors have no conflict of interest to declare.

НаАійшло Ао редакції / Received: 06.06.2017

Після Аоопрацювання / Revised: 12.06.2017

Прийнято Ао Аруку / Accepted: 04.09.2017 